\title{
PERBUATAN MELAWAN HUKUM TERHADAP PEMALSUAN AKTA OTENTIK YANG DILAKUKAN NOTARIS
}

\author{
Wahyudin, SH / Dr. H. Jarot Widya Muliawan, SH, C.N, M.kn Magister \\ Kenotariatan Fakultas hukum Universitas narotama Surabaya Email : \\ Wahyudinwahyu21529@gmail.com
}

\begin{abstract}
This research uses the Conceptual Approach Method and the Law Approach Method, on Normative Juridical Analysis by combining two data collection methods, namely Studying the Law and Examining library materials or secondary materials which are then analyzed using the Qualitative Analysis Method.

The research results show that the notary can only (legally / in accordance with the rule of law) be a suspect if the notary intentionally keeps making a fake deed as requested by the tapper, even though he knows that the parties do not meet the legal requirements of the engagement. This shows that the notary does not strictly adhere to the Law on Notary Position (UUJN) and the Notary Professional Code of Ethics. Where it can lead to a notary public criminal act of forgery of authentic letters / deeds.

The position of a Notary is held or its presence is desired by the laws and regulations with the intention of helping and serving people who need authentic written evidence regarding circumstances of events or legal actions of direct involvement by the parties facing them. However, in carrying out his profession, the police law apparatus is often summoned as a suspect in connection with the forgery of authentic deeds he has made. Thus, it is deemed necessary to know the Normative Juridical Analysis of Authentic Deed Falsification Conducted by Notaries.
\end{abstract}

Keywords: Notary, Authentic Deed Falsification, Suspect.

\begin{abstract}
Abstrak
Penelitian ini menggunakan Metode Pendekatan Konseptual dan Metode Pendekatan Undang-Undang, tentang Analisis Yuridis Normatif dengan cara menggabungkan dua metode pengumpulan data yaitu Menelaah UndangUndang dan Meneliti bahan pustaka atau bahan sekunder yang Kemudian dianalisa dengan Metode Analisis Kualitatif.

Hasil Penelitian menunjukkan bahwa notaris hanya dapat (legal/sesuai dengan aturan hukum) dijadikan sebagai tersangka apabila notaris tersebut dengan sengaja tetap membuat akta palsu sesuai yang diminta oleh penghadap, padahal ia mengetahui bahwa para pihak penghadap tersebut tidak memenuhi syarat-syarat sahnya perikatan. Hal ini menunjukkan bahwa notaris tersebut tidak berpegang teguh pada Undang-Undang Jabatan
\end{abstract}


Notaris (UUJN) dan Kode Etik Profesi Notaris. Dimana dapat menjerumuskan notaris mengarah pada tindak pidana pemalsuan surat/akta otentik.

Jabatan Notaris diadakan atau kehadirannya dikehendaki oleh Peraturan Perundang- undangan dengan maksud untuk membantu dan melayani masyarakat yang membutuhkan alat bukti tertulis yang bersifat otentik, mengenai keadaan peristiwa atau perbuatan hukum atas keterlibatan langsung oleh para pihak yang menghadap. Namun demikian Notaris dalam menjalankan profesinya tidak jarang dipanggil oleh pihak aparat hukum kepolisian sebagai tersangka Sehubungan dengan pemalsuan akta otentik yang dibuatnya. Sehingga, dipandang perlu untuk mengetahui Analisis Yuridis Normatif Terhadap Pemalsuan Akta Otentik Yang Dilakukan Oleh Notaris.

Kata kunci: Notaris, Pemalsuan Akta Otentik, Tersangka.

\section{PENDAHULUAN}

\section{A. Latar Belakang}

Notaris adalah pejabat umum yang berwenang untuk membuat akta otentik, sejauh pembuatan akta otentik tersebut tidak dikhususkan kepada Pejabat umum lainnya. Pembuatan akta otentik ada yang diharuskan oleh Peraturan Perundang- undangan dalam rangka menciptakan kepastian, ketertiban dan perlindungan hukum. Selain akta otentik yang dibuat oleh atau dihadapan notaris bukan saja karena diharuskan oleh tetapi juga dikehendaki oleh pihak yang berkepentingan untuk memastikan hak dan kewajiban para pihak demi kepastian, ketertiban dan perlindungan hukum bagi pihak yang berkepentingan sekaligus bagi masyarakat secara keseluruhan. ${ }^{1}$

Akta Notaris lahir karena adanya keterlibatan langsung dari pihak yang menghadap notaris, merekalah yang menjadi pemeran utama dalam pembuatan sebuah akta sehingga tercipta sebuah akta yang otentik. Akta Notaris adalah akta otentik yang dibuat oleh atau dihadapan Notaris menurut bentuk dan tata cara yang ditetapkan dalam Undang-undang. Akta yang dibuat notaris menguraikan secara otentik mengenai semua perbuatan, perjanjian dan penetapan yang disaksikan oleh para penghadap dan saksisaksi. $^{2}$

\footnotetext{
${ }^{1}$ Penjelasan Undang-undang Nomor 30 Tahun 2004 Tentang Jabatan Notaris

2 Wawan Tunggal Alam, Hukum Bicara Kasus-kasus dalam Kehidupan Sehari-hari
} Milenia Populer, Jakarta, 2001, h.85. 
Akta yang dibuat oleh notaris harus mengandung syarat-syarat yang diperlukan agar tercapai sifat otentik dari akta itu misalnya dalam pembacaan akta menerangkan bahwa harus mencantumkan identitas para pihak, membuat isi perjanjian yang dikehendaki para pihak, menandatangani akta dan sebagainya. Tetapi apabila syarat- syarat itu tidak terpenuhi maka akta tersebut dapat dibatalkan atau batal demi hukum.

Tujuan pembacaan akta ini adalah agar para pihak saling mengetahui isi dari akta tersebut seb ab isi dari akta itu merupakan kehendak para pihak. Pembacaan akta ini juga dilakukan agar pihak yang satu tidak merasa dirugikan apabila terdapat keterangan atau redaksi akta yang memberatkan atau merugikan terhadap pihak yang lain.

Begitu pentingnya peranan Notaris yang diberikan oleh Negara, dimana Notaris sebagai pejabat umum dituntut bertanggung jawab terhadap akta yang dibuatnya. Karena Seorang Notaris haruslah tunduk kepada peraturan yang berlaku yaitu Undang-undang Jabatan Notaris dan taat kepada kode etik profesi hukum. Kode etik yang dimaksud disini adalah kode etik Notaris. Apabila akta yang dibuat ternyata dibelakang hari mengandung sengketa maka hal ini perlu dipertanyakan, apakah akta ini merupakan kesalahan notaris dengan sengaja untuk menguntungkan salah satu pihak penghadap atau kesalahan para pihak yang tidak memberikan dokumen yang sebenarnya. Apabila akta yang dibuat/diterbitkan notaris mengandung cacat hukum karena kesalahan notaris baik karena kelalaian maupun karena kesengajaan notaris itu sendiri maka notaris harus memberikan pertanggungjawaban secara moral dan secara hukum. Dan tentunya hal ini harus terlebih dahulu dapat dibuktikan.

Oleh karena itu jika Notaris terbukti melakukan kesalahan-kesalahan baik yang bersifat pribadi maupun yang menyangkut profesionalitas dalam suatu pembuatan akta yang mengandung unsur melawan hukum maka beberapa tahap prosedur yang dapat dikemukakan dilapangan adalah antara lain Pemanggilan notaris sebagai saksi, kemudian ditingkatkan sebagai tergugat dipengadilan perdata menyangkut pertanggungjawaban akta yang dibuat untuk dijadikan alat bukti yang sebelumnya adanya toleransi dari Majelis 
Pengawas Notaris, selanjutnya ditindaklanjuti dengan pemidanaan yakni Notaris dapat dijadikan saksi dan tersangka dalam kasus pidana serta penyitaan bundel minuta yang disimpan oleh Notaris. ${ }^{3}$

Notaris rawan terkena jeratan hukum. Bukan hanya karena faktor internal yang berasal dari dalam dirinya sendiri misalnya kecerobohan, tidak mematuhi prosedur, tidak menjalankan etika profesi dan sebagainya. Namun juga dikarenakan faktor internal seperti moral masyarakat dimana Notaris dihadapkan pada dokumen- dukumen palsu padahal dokumen tersebut mengandung konsekuensi hukum bagi pemiliknya. ${ }^{4}$

Demikian disimpulkan bahwa walaupun didalam Undang-undang jabatan notaris (UUJN) tidak menyebutkan adanya penerapan sanksi pemidanaan tetapi suatu tindakan hukum terhadap pelanggaran yang dilakukan oleh Notaris tersebut mengundang unsur- unsur pemalsuan atas kesengajaan/kelalaian dalam pembuatan surat/akta otentik yang keterangan isinya palsu maka setelah dijatuhi sanksi administratif/kode etik profesi jabatan notaris dan sanksi keperdataan kemudian dapat ditarik dan dikualifikasikan sebagai suatu tindak pidana yang dilakukan oleh Notaris yang menerangkan adanya bukti keterlibatan secara sengaja melakukan kejahatan pemalsuan akta otentik. ${ }^{5}$

Hukum Pidana merupakan bagian dari hukum publik yang mengutamakan tekanan dari kepentingan umum pada masyarakat. Menurut doktrin adanya suatu pertanggungjawaban pidana harus terpenuhinya syarat yaitu dengan melihat adanya perbuatan yang dapat dihukum dengan menyebutkan unsurunsurnya secara tegas dan berdasarkan undang- undang yang mengatur bahwa perbuatan tersebut telah bertentangan dengan hukum yang menimbulkan kejahatan pidana, dimana harus mempertanggungjawabkan Sebab-akibat dari pada perbuatan tersebut. ${ }^{6}$

${ }^{3}$ Majalah Renvoi Nomor 3.39.IV, Agustus, 2006, h.54.

${ }^{4}$ Pengurus Pusat Ikatan Notaris Indonesia, Jati Diri Notaris Indonesia Dulu, Sekarang dan Dimasa Datang, Jakarta: PT. Gramedia Pustaka Utama, 2008, h.226.

${ }^{5}$ Habib adjie, Hukum Notaris Indonesia, Bandung: Refika Aditama, 2008, h.25.

${ }^{6}$ Majalah Renvoi, Op. Cit., hal.57. 
Dengan terjadinya kasus/perkara semacam ini maka akan menyebabkan notaris harus keluar masuk gedung pengadilan untuk mempertanggungjawabkan akta yang telah dibuatnya, mengingat notaris merupakan pejabat umum yang berwenang membuat akta otentik dimana dibuat setelah ditandatangani oleh para pihak dan menjadi Dokumen Negara.

Sehubungan dengan hal tersebut Penulis tertarik untuk Membahas dan Menganalisis mengenai, Perbuatan melawan hukum Terhadap Pemalsuan Akta Otentik Yang Dilakukan Oleh Notaris Dan Bagaimana Akibat Hukumnya Terhadap Pemalsuan Akta Otentik Yang Dilakukan Oleh Notaris.

\section{B. Rumusan Masalah :}

Berdasarkan latar belakang yang diuraikan diatas maka yang menjadi pokok permasalahan adalah sebagai berikut :

1. Unsur-Unsur Perbuatan Pidana Terhadap Pemalsuan Akta Otentik Yang Dilakukan Oleh Notaris?

2. akibat Hukum terhadap pemalsuan akta otentik yang dilakukan oleh Notaris?

\section{Tujuan Penelitian}

Pertama membahas tentang Unsur - Unsur pidana terhadap pemalsuan Akta otentik yang dilakukan oleh notaris ? dan yang kedua membahas Akibat hukum terhadap pemalsuan akta otentik yang dilakukan oleh notaris

\section{Manfaat Penelitian}

Dalam penelitian ini diharapkan dapat memberi manfaat baik secara teoritis maupun secara praktis, yakni:

1. Secara Teoritis

Hasil penelitian ini diharapkan dapat bermanfaat dalam memberikan penambahan ilmu pengetahuan yang dapat digunakan oleh pihak yang membutuhkan sebagai bahan kajian pada umumnya, khususnya pengetahuan dalam hal Mengetahui dan Mempelajari tentang Analisis 
Yuridis Normatif Terhadap Pemalsuan Akta Otentik yang dilakukan oleh Notaris.

\section{Secara Praktis}

Hasil penelitian ini diharapkan bermanfaat bagi para mahasiswa dan masyarakat khususnya bagi para calon notaris dalam hal mengetahui secara jelas tentang Perumusan Unsur-Unsur Perbuatan Pidana Terhadap Pemalsuan Akta Otentik Yang Dilakukan Oleh Notaris dan Akibat Hukum Terhadap Pemalsuan Akta Otentik Yang Dilakukan Oleh Notaris.

\section{E. Metode penelitian}

Suatu Metode merupakan cara kerja atau tata kerja untuk dapat memahami obyek yang menjadi sasaran dari ilmu pengetahuan yang bersangkutan. Metode adalah pedoman cara seorang ilmuan mempelajari dan memahami langkah-langkah yang dihadapi. ${ }^{7}$

Sedangkan Penelitian adalah suatu kegiatan untuk mencari, mencatat, merumuskan dan menganalisis sampai menyusun laporan. ${ }^{8}$

${ }^{7}$ Soejono soekanto dan sri mamudji "Penelitian hukum normatif suatu tinjauan singkat" ed.1,cet 10.Jakarta: raja grafindo persada,2007,h.6.

${ }^{8}$ Cholid Narbuko, Abu Achmadi, Metodologi penelitian Jakarta: Bumi Pustaka,1997 h.1. 


\section{Pembahasan}

\section{a. Unsur-Unsur Perbuatan Pidana Terhadap Pemalsuan Akta Otentik Yang Dilakukan Oleh Notaris}

Berdasarkan Perumusan unsur-unsur pidana dari bunyi pasal 263 KUHP mengenai pemalsuan akta otentik yang dilakukan oleh Notaris tidak bisa diterapkan kepada pelaku yakni Notaris yang memalsu akta otentik. Akan tetapi Notaris tersebut dapat dikenakan sanksi dari pasal 264 KUHP, sebab pasal 264 KUHP merupakan Pemalsuan surat yang diperberat dikarenakan obyek pemalsuan ini mengandung nilai kepercayaan yang tinggi. Sehingga semua unsur yang membedakan antara pasal 263 dengan pasal 264 KUHP hanya terletak pada adanya obyek pemalsuan yaitu "Macam surat dan surat yang mengandung kepercayaan yang lebih besar akan kebenaran isinya. ${ }^{9}$

Notaris dapat dikenakan sanksi pasal 264 KUHP apabila terbukti telah melakukan pemalsuan akta otentik.

Pasal 264 merumuskan sebagai berikut:

1. Menjelaskan bahwa pemalsuan surat diancam dengan pidana penjara paling lama delapan (8) tahun jika dilakukan terhadap:

a. Akta Otentik;

b. Surat hutang dan sertifikat hutang dari suatu negara atau bagiannya ataupun dari suatu lembaga umum

c. Surat sero atau hutang atau sertifikat sero atau hutang dari suatu perkumpulan, yayasan, perseroan atau maskapai

d. Talon, tanda bukti deviden atau bunga dari salah satu surat yang diterangkan dalam 2 dan 3 atau tanda bukti yang dikeluarkan sebagai pengganti surat- surat itu.

e. Surat kredit atau surat dagang yang disediakan untuk diedarkan.

2. Diancam dengan pidana yang sama barang siapa yang sengaja memakai surat tersebut dalam ayat pertama, yang isinya tidak sejati atau yang dipalsukan seolah-olah benar dan tidak dipalsu jika pemalsuan surat itu dapat menimbulkan kerugian nyatalah bahwa yang

\footnotetext{
${ }^{9}$ Adamichazawi, Op.Cit. hal. 107
} 
menyebabkan diperberatnya pemalsuan surat pasal 264 diatas terletak pada faktor macam-macamnya surat. Surat-surat tertentu yang menjadi objek kejahatan adalah surat-surat yang mengandung kepercayaan yang lebih besar akan kebenaran isinya. Pada surat-surat itu mempunyai derajat kebenaran yang lebih tinggi dari pada surat- surat biasa atau surat-lainnya. Kepercayaan yang lebih besar terhadap kebenaran akan isi dari macammacam surat itulah yang menyebabkan di perberat ancaman pidananya. ${ }^{10}$

Penyerangan terhadap kepercayaan masyarakat yang lebih besar terhadap isi surat-surat yang demikian dianggap membahayakan kepentingan umum masyarakat yang lebih besar pula.

Ada 2 kejahatan yang dirumuskan dalam pasal 264 yang masing-masing dirumuskan dalam ayat (1) dan (2) Kejahatan pada ayat (1) mempunyai unsur- unsur sebagai berikut:

1. Semua unsur baik obyektif maupun subyektif pasal 263.

2. Unsur-unsur khusus pemberatnya (bersifat alternatif) berupa obyek surat- surat tertentu, ialah:

1. Akta otentik

2. Surat hutang dan sertifikat hutang dari suatu negara atau bagiannya ataupun dari suatu lembaga umum

3. Surat sero atau hutang atau sertifikat sero atau hutang dari suatu perkumpulan, yayasan, perseroan atau maskapai

4. Talon, tanda bukti deviden atau bunga dari salah satu surat yang diterangkan dalam 2 dan 3 atau tanda bukti yang dikeluarkan sebagai pengganti surat- surat itu.

5. Surat kredit atau surat dagang yang disediakan untuk diedarkan. ${ }^{11}$

${ }^{10}$ Ibid, h.108.

${ }^{11}$ Ibid, h. 110. 


\section{B. Akibat Hukum Terhadap Pemalsuan Akta Otentik Yang Dilakukan Oleh Notaris}

Akibat hukum terhadap pemalsuan akta otentik yang dilakukan oleh notaris yaitu Pada dasarnya terjadi suatu perkara dimana pejabat umum telah mencari-cari keuntungan serta menyalahgunakan kewenangan yang telah diatur dalam peraturan Undang-Undang Jabatan Notaris dan seorang klien/penghadap lainnya merasa dirugikan atas terbuatnya suatu akta yang mengandung keterangan palsu oleh notaris. Maka mengenai pembatalan akta adalah menjadi kewenangan hakim perdata, yakni dengan mengajukan gugatan secara perdata kepengadilan.

Apabila dalam persidangan dimintakan pembatalan akta oleh pihak yang dirugikan (pihak korban) maka akta notaris tersebut dapat dibatalkan oleh hakim perdata jika ada bukti lawan. Sebagaimana diketahui bahwa akta notaris adalah akta otentik yang merupakan alat bukti tertulis yang mempunyai kekuatan pembuktian yang mengikat dan sempurna. Ini berarti bahwa masih dimungkinkan dapat dilumpuhkan oleh bukti lawan yakni diajukannya gugatan untuk menuntut pembatalan akta ke pengadilan agar akta tersebut dibatalkan.

Pembatalan menimbulkan keadaan tidak pasti, oleh karena itu UndangUndang memberikan waktu terbatas dalam hal menuntut dimana oleh Undang- undang dapat dilakukan pembatalan apabila hendak melindungi seseorang terhadap dirinya sendiri. Dengan demikian dalam suatu putusan oleh hakim perdata selama tidak dimintakan pembatalan maka perbuatan hukum/perjanjian yang tercantum dalam akta tersebut akan tetap berlaku atau sah.

Setelah adanya putusan hakim yang berkekuatan hukum tetap atas gugatan penuntutan pembatalan akta tersebut maka akta itu tidak lagi mempunyai kekuatan hukum sebagai alat bukti yang otentik karena mengandung cacat secara yuridis/cacat hukum, maka dalam amar putusan hakim perdata akan menyatakan bahwa akta tersebut batal demi hukum. Dan berlakunya pembatalan akta tersebut adalah berlaku surut yakni sejak perbuatan hukum/perjanjian itu dibuat. 
Pembatalan terhadap suatu akta otentik dapat juga dilakukan oleh notaris apabila para pihak/penghadap menyadari adanya kekeliruan atau kesalahan yang telah dituangkan dalam akta tersebut. Sehingga dapat membuat keraguan terhadap kesepakatan/perjanjian dari para pihak/penghadap, maka akta tersebut dapat dibatalkan oleh notaris.

Bilamana notaris terseret dalam perkara pemalsuan akta yang menjadi aktor intelektualnya atau notaris turut serta ikut melakukan pemalsuan surat yang bisa dikategorikan dalam perbuatan tindak pidana tersebut maka secara yuridis tidak dapat ditolelir bukan hanya berdasarkan ketentuan pidana saja, tetapi juga oleh Peraturan BW KUHPerdata serta Peraturan Undang-Undang Jabatan Notaris (UUJN).

Adapun beberapa penerapan sanksi Jika notaris terbukti telah melakukan suatu pemalsuan akta otentik maka sanksi yang dapat dikenakan kepada Notaris yang melakukan pelanggaran hukum yaitu:

1. Menurut Undang-Undang Nomor 30 tahun 2004 tentang Jabatan Notaris yaitu penerapan sanksi Administratif atau Kode Etik Notaris.

Secara Administratif instrument penegakan hukum dalam UndangUndang Jabatan Notaris, meliputi langkah preventif (Pengawasan) dan langkah represif (Penerapan sanksi). Langkah preventif dilakukan melalui pemeriksaan protocol notaris secara berkala dan kemungkinan adanya pelanggaran kode etik dalam pelaksanaan jabatan notaris. Sedangkan langkah represif dilakukan melalui penjatuhan sanksi oleh:

a. Majelis Pengawas Wilayah, berupa teguran lisan dan teguran tertulis serta berhak mengusulkan kepada Majelis Pengawas Pusat pemberhentian sementara (Tiga) 3 bulan sampai dengan (Enam) 6 bulan dan pemberhentian tidak hormat.

b. Majelis Pengawas Pusat, berupa pemberhentian sementara serta berhak mengusulkan kepada menteri berupa pemberhentian dengan tidak hormat.

c. Menteri, berupa pemberhentian dengan tidak hormat dan 
pemberhentian tidak hormat. 12

\section{Menurut Kitab Undang-Undang Hukum Pidana}

Terjadinya pemidanaan terhadap notaris berdasarkan akta yang dibuat oleh atau di hadapan notaris sebagai bagian dari pelaksanaan tugas jabatan atau kewenangan notaris, tanpa memperhatikan aturan hukum yang berkaitan dengan tata cara pembuatan akta dan hanya berdasarkan ketentuan Kitab Undang-Undang Hukum Pidana (KUHP) saja, menunjukkan telah terjadinya kesalahpahaman atau penafsiran terhadap kedudukan notaris sedangkan akta notaris sebagai alat bukti dalam hukum perdata.

Sanksi pidana merupakan ultimum remedium yaitu obat terakhir, apabila sanksi atau upaya-upaya pada cabang hukum lainnya tidak mempan atau dianggap tidak mempan. ${ }^{13}$

Bagi notaris yang melakukan tindak pidana dapat dilakukan pemberhentian oleh Menteri dengan alasan notaris telah terbukti bersalah dan dikenakan ancaman pidana penjara, yang diatur dalam Keputusan Menteri tahun 2003 tentang Kenotariatan pasal 21 ayat (2) sub b yaitu Notaris terbuktibersalah yang berkaitan langsung dengan jabatannya atau tindak pidana lain dengan ancaman pidana 5 (lima) tahun penjara.

Dalam Penjatuhan sanksi perdata, administratif bahkan pidana mempunyai sasaran, sifat, dan prosedur yang berbeda. Sanksi Administratif maupun Sanksi Perdata dengan sasaran yaitu perbuatan yang dilakukan oleh yang bersangkutan dan sanksi pidana dengan sasaran yaitu pelaku (orang) yang melakukan tindakan hukum tersebut.

\footnotetext{
${ }^{12}$ Ibid, pasal 77 butir c.

${ }^{13}$ Habib Adjie, Jurnal Renvoi, Nomor 10-22 Tanggal 3 Maret 2005, h.126.
} 


\section{KESIMPULAN}

Berdasarkan hasil penelitian dan pembahasan yang telah diuraikan dengan pokok permasalahan yang telah dirumuskan maka dapat ditarik kesimpulan sebagai berikut bahwa:

1. Perumusan Unsur-Unsur Perbuatan Pidana Terhadap Pemalsuan Akta Otentik Yang Dilakukan Oleh Notaris adalah Suatu Proses sanksi Hukum pidana yang diterapkan dimana jika notaris terbukti telah melakukan kejahatan Pemalsuan Akta dapat dikenakan Pasal 264 KUHP. Berdasarkan Perumusan unsur-unsur pidana dari bunyi pasal 263 KUHP mengenai pemalsuan akta otentik yang dilakukan oleh Notaris tidak bisa diterapkan kepada pelaku yakni Notaris yang memalsu akta otentik. Akan tetapi Notaris tersebut dapat dikenakan sanksi dari pasal 264 KUHP, sebab pasal 264 KUHP merupakan Pemalsuan surat yang diperberat dikarenakan obyek pemalsuan ini mengandung nilai kepercayaan yang tinggi. Sehingga semua unsur yang membedakan antara pasal 263 dengan pasal 264 KUHP hanya terletak pada adanya obyek pemalsuan yaitu "Macam surat dan surat yang mengandung kepercayaan yang lebih besar akan kebenaran isinya" Sedangkan pelaku yang menyuruh notaris membuat surat/akta palsu dapat dikenakan sanksi pidana pasal 266 KUHP

\section{DAFTAR PUSTAKA}

\section{Buku}

Wawan Tunggal Alam, Hukum Bicara (Kasus-kasus Hukum dalam Kehidupan Sehari- hari), Milenia Popular, Jakarta, 2001

Habib adjie, Hukum Notaris Indonesia, Bandung: Refika Aditama, 2008

Chazawi, Adami, Kejahatan Terhadap Pemalsuan, PT. Raja Grafindo Persada, Jakarta, 2000

Cholid Narbuko, Abu Achmadi, Metodologi penelitian Jakarta: Bumi Pustaka, 1997

Sukanto, Soerdjono dan Sri Mamudji, Penelitian Hukum Normatif Suatu Tinjauan Singkat, Rajawali Press, Jakarta, 1995 


\section{Peraturan Perundang-undangan}

Undang-undang No. 30 Tahun 2004 Tentang Undang-undang Jabatan Notaris Kitab Undang-undang Hukum Pidana (Wetboek Van Strafrecht, Staatsblad 1915 No. 732)

\section{Majalah :}

Renvoi Nomor : 9.21. II Tanggal 3 Februari2005 Nomor : 10.22. II Tanggal 3 Maret2005 Nomor : 3.39.IV, Agustus,2006 